\section{Intensivbehandling for viderekomne}

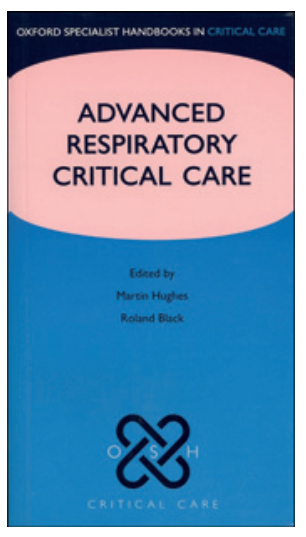

Martin Hughes, Roland Black, red. Advanced respiratory critical care

590 s, tab, ill. Oxford: Oxford University Press, 2011. Pris GBP 43

ISBN 978-0-19-956928-1

Respirasjonssvikt kan gi $\mathrm{O}_{2-}$ mangel i blodet, stigning av $\mathrm{CO}_{2}$ eller begge deler. Økning av $\mathrm{O}_{2}$-innholdet $\mathrm{i}$ inspirasjonsgassen og av gjennomsnittstrykket i luftveiene gjør at flere fungerende alveoler får økt oksygentrykk, og $\mathrm{O}_{2}$-innholdet i blodet øker. Ved alvorlig respirasjonssvikt er respirasjonsarbeidet betydelig økt. En ond sirkel oppstår når utmattelse reduserer ventilasjonsevnen, som igjen reduserer oksygeneringsevnen. I slike situasjoner blir overtrykksventilasjon i form av respiratorbehandling livreddende. Slik ventilasjon har også mange negative effekter, som at inspirasjonsgassen omfordeles til lungeområder med dårligere blodforsyning og at $ø k t$ intratorakalt trykk ofte reduserer hjertets pumpeevne. Bruk av store tidevolum og høye luftveistrykk kan i akuttsituasjoner bedre $\mathrm{O}_{2}$-innholdet i blodet betydelig, men kan også skade friskt så vel som sykt lungevev og opprettholde betennelsesprosesser i lungene.

Kortvarig ventilasjon av hjerte- og lungefriske gir sjelden komplikasjoner. Hos pasienter med alvorlig lungesvikt, hvor behandlingen går over dager og uker, er det imidlertid viktig å velge kombinasjoner av tidevolum, luftveistrykk, $\mathrm{O}_{2}$-fraksjon, respirasjonsfrekvens etc., som sikrer adekvat oksygenering av blodet samtidig som faren for skadevirkninger holdes så lav som mulig.

Siden overtrykksventilasjon ved respirasjonssvikt ble vanlig i 1950- og 60-årene har mange forskergrupper forsøkt å finne frem til hvilke ventilasjonsmønstre som gir et optimalt forhold mellom de positive og negative effektene av overtrykksventilasjon. Pasienter med alvorlig respirasjonssvikt er imidlertid en svært heterogen gruppe, både når det gjelder etiologi og anatomiske/patofysiologiske sykdomsforandringer i lungene. Mange av pasientene har også kompliserende tilleggssykdommer. Selv om flere forskergrupper med stor styrke har fremhevet sine vitenskapelig baserte anbefalinger som allmenngyldige, bør de betraktes som veiledende. Da det neppe er mulig å finne enhetlige retningslinjer for ett ventilasjonsmønster som gir optimalt resultat hos alle pasienter, stiller behandling av alvorlig respirasjonssvikt krav til gode kunnskaper om kardiopulmonal fysiologi og patofysiologi, i tillegg til evne til kritisk vurdering av vitenskapelige data.
Målgruppen er leger med ansvar for å behandle pasienter med alvorlig respirasjonssvikt i overvåkings- og intensivavdelinger, i Norge vil dette først og fremst være anestesileger. Boken har 74 forfattere og er redigert av to intensivmedisinere, som beskriver den som en mellomting mellom enkle, kortfattede retningslinjer og store, omfattende håndbøker. I pocketbokformat og med liten skrift på 590 tettpakkede sider har man fått plass til svært mye informasjon. Indeksregisteret er meget bra, og illustrasjonene er relativt få, men informative.

Stoffet er delt i seks hovedseksjoner. Seksjon 1 er en generell innføring i diagnostikk og behandling, og seksjon 2-4 omhandler forskjellige metoder for noninvasiv og invasiv behandling av respirasjonssvikt. Det er en utmerket oversikt over konvensjonelle og avanserte behandlingsopsjoner. Disse delene er kanskje de beste. I seksjon 5 beskriver forfatterne en del relevante forhold rundt praktisk respiratorbehandling, og i seksjon 6 gir de anbefalinger om behandling av respirasjonssvikt, oppdelt etter underliggende årsak.

Boken er utrolig innholdsrik, både når det gjelder omtale av patofysiologiske mekanismer, nyere forskningsresultater og praktiske retningslinjer for behandling. For å få plass til mest mulig informasjon er den delvis skrevet $i$ telegramstil med punktvis oppstilling av momenter - etter min mening går da noe av dynamikken i sykdomsprosessene tapt, og det blir vanskelig for leger uten god bakgrunnskunnskap å skjelne mellom vesentlig og mindre viktig informasjon.

Som man kan vente av en bok med så mange forfattere, er kvaliteten ujevn. I de beste delene veksler teksten mellom punktvise oversikter og korte og konsise forklaringer på en forbilledlig måte, og nyere studier kommenteres balansert og innsiktsfullt. I andre deler virker det som om forfatterne har begrenset erfaring med både intensivbehandling av respiratorpasienter og kritisk vurdering av forskningsresultater. Et eksempel på dette er at man på to steder anbefaler å behandle pasientene med væskerestriksjon hvor målsettingen er et sentralt venetrykk $(\mathrm{CVP})<4 \mathrm{~mm} \mathrm{Hg}$. Mens væskerestriksjon er gunstig for syke lunger isolert sett, tilsier klinisk erfaring at restriksjon ned til dette nivået er vanskelig og til dels farlig hos mange slike pasienter. Det var da heller ikke mulig å oppnå dette hos de fleste pasientene i den studien man refererer til.

Det er enkelte skjønnhets-, trykk- og andre feil, f.eks. presenterer forfatterne helt identiske figurer i to forskjellige kapitler. At tyngdekraften påvirker ned til $10 \%$ av forskjellene i regional blodstrøm i lungene er heller ikke noe alle vil være enige $i$.

Boken egner seg best for dem som har en del erfaring med intensivbehandling av pasienter med akutt respirasjonssvikt. For leger som skal avlegge spesialisteksamen i anestesiologi og intensivmedisin, representerer den en solid kunnskapsbase.

\section{Helge Opdahl}

NBC-senteret

Akuttmedisinsk avdeling

Oslo universitetssykehus, Ullevål 